\title{
Correction to: Novel dynamic load balancing algorithm for cloud-based big data analytics
}

\section{Arman Aghdashi ${ }^{1}$. Seyedeh Leili Mirtaheri ${ }^{1}$}

Published online: 10 September 2021

(c) Springer Science+Business Media, LLC, part of Springer Nature 2021

\section{Correction to: The Journal of Supercomputing https://doi.org/10.1007/s11227-021-04024-8}

In this article, ref. 7 was incorrect.

The correct version is given below:

Khatibi E, Mirtaheri SL (2019) A dynamic data dissemination mechanism for Cassandra NoSQL data store. J Supercomput 75(11):7479-7496. https://doi.org/10. 1007/s11227-019-02959-7

The original article has been corrected.

Publisher's Note Springer Nature remains neutral with regard to jurisdictional claims in published maps and institutional affiliations.

The original article can be found online at https://doi.org/10.1007/s11227-021-04024-8.

Seyedeh Leili Mirtaheri

Mirtaheri@khu.ac.ir

1 Department of Electrical and Computer Engineering, Faculty of Engineering, Kharazmi

University, Tehran, Iran 